B. Iegorov ${ }^{1}$, Dr. of Technical Sciences, Professor, E-mail: bogdanegoroff58@ gmail.com, https://orcid.org/0000-0001-7526-0315, ResearcherID: Q-1365-2015, Scopus Author ID: 56578802600

N. Khorenzhy², PhD., Associate professor, Candidate of technical science, E-mail: natalka.onaft@ gmail.com, http://orcid.org/0000-0001-7912-4791 ResearcherID: B-3897-2016 ${ }^{I}$ Department of Feed and Biofuel Technologies

2 Department of Grain Processing Odessa National Academy of Food Technologies, 112, Kanatna Str., Odessa, Ukraine, 65039

\title{
DETERMINATION OF THE INTERNAL POTENTIAL OF ENERGY EFFICIENCY IN COMPOUND FEED PRODUCTION
}

\begin{abstract}
Annotation.
Grass flour is a unique protein-vitamin feed product, the role of which in animal feeding can hardly be overestimated. In 2010, the industry for the production of grass meal from alfalfa, for example, in Europe included 300 factories and 50 farms, which produced 4200 million tons of products. In Russia, the development of poultry and livestock farming has also increased the demand for this fodder and gradually restored its production. But in Ukraine, due to its high energy intensity, the production of herbal flour has almost ceased. It is shown that the fuel and energy balance of this technology that diesel fuel provides about $92.3 \%$ of all equipment needs for energy, and its cost is $90.8 \%$ of the total cost of all fuel and energy resources (FER). On the other hand, electricity accounts for only $7.7 \%$ of the total needs, and the costs of paying for it also serve $9.2 \%$ of the total costs of purchasing fuel and energy resources.

The purpose of the work is to study the energy feasibility of using extrusion for dehydration of wet feed products during their complex processing in feed products. To achieve this goal, the following tasks were solved: the selection and calculation of the necessary technological equipment for the principle technological scheme of the production of feed products with the inclusion of wet forage grasses was carried out; an energy audit of the basic (traditional) and new technologies for the production of compound feed products with the inclusion of forage grasses was carried out. Since the new technology is recommended to be implemented at feed mills of small capacity due to the proximity of raw materials, it must be able to process forage grasses in an amount no less than the basic technology for the production of grass meal. The minimum capacity of the ABM-type drying unit for cooking is 0.65 t/h for grass meal (2.7 t/h for raw materials). Thus, an energy audit of the basic (traditional) and new technology for the production of mixed feed products with the inclusion of forage grasses was carried out and proved that as a result of the use of the extrusion process for the purpose of dehydration, the new technology becomes more energy efficient in comparison with the traditional technology of drying forage grasses and further production of products with the inclusion of grass flour, which means it is economically feasible, since there is a total saving of fuel and energy resources of $875 \mathrm{MJ} / \mathrm{t}$ or - in the amount of $514.18 \mathrm{UAH}(44 \%)$.
\end{abstract}

Key words: energy efficiency, electricity, fuel, fuel and energy resources, extrusion, compound feed, herbal meal.

\section{Introduction}

Despite the status of an energy-deficient country, Ukraine is one of the world leaders in terms of energy intensity of production. High energy costs for the production lead to a decrease in the competitiveness of the products obtained both in the domestic and foreign markets, a decrease in the level of economic and energy security of the country [1-3].

The constant rise in prices for electricity, fuel, gas forces the population and producers to resort to energy-saving measures. After all, it is known that the cost of implementing energy-saving measures is 2 - 3 times less than the cost of extracting energy resources or purchasing them $[4,5]$. But the development and implementation of energy efficient technologies that would reduce their total energy intensity without reducing production volumes seems to be more urgent. \section{statement}

Analysis of literature data and problem

Grass flour is a unique protein-vitamin feed product, the role of which in animal feeding can hardly be overestimated. Grass flour production in the world began in the early 50 s of the last century with the aim of producing a nutritious fodder alternative to hay or haylage, with minimal losses of nutrients and biological- ly active substances [6]. Now it has a permanent technology, the main stages and modes of which are almost the same throughout the world. The traditional method of obtaining granulated grass meal involves mowing leguminous grasses with a moisture content of more than $70 \%$ at the budding stage (cereals - at the stage of entering the tube) with simultaneous grinding, loading this mass into vehicles that supply it to the drying unit, hightemperature drying to the final moisture $9-12 \%$, grinding, granulating and cooling [7-11]. Further use of this fodder agent in compound feed production is accompanied by its purification from impurities, grinding, dosing and mixing with other components, as well as, if necessary, granulation of loose compound feed.

In 2010, the industry for the production of grass meal from alfalfa, for example, in Europe included 300 factories and 50 farms, which produced 4200 million tons of products [12]. In Russia, the development of poultry and livestock farming has also increased the demand for this fodder and gradually restored its production [6]. But in Ukraine, due to its high energy intensity, the production of herbal flour has almost ceased.

In the industrial production of granulated grass flour, equipment is used, for example, of the following configuration: the Volgar-5A grinder, an AVM-1.5 R drying unit and a set of equipment for granulating OGM-

Table 1 - Fuel and energy balance of technology per unit of product 


\begin{tabular}{|c|c|c|c|c|c|c|c|c|}
\hline \multirow{2}{*}{$\begin{array}{l}\text { Fuel and energy } \\
\text { resources } \\
\text { (FER) }\end{array}$} & \multirow{2}{*}{$\begin{array}{l}\text { Conver- } \\
\text { sion factor } \\
\text { in } \mathrm{kWh}\end{array}$} & \multicolumn{2}{|c|}{ Energy equivalent } & \multirow{2}{*}{$\begin{array}{c}\% \\
\text { energy }\end{array}$} & \multirow{2}{*}{$\begin{array}{l}\text { Cost, } \\
\text { UAH }\end{array}$} & \multirow{2}{*}{$\begin{array}{l}\% \text { of } \\
\text { the } \\
\text { cost }\end{array}$} & \multirow{2}{*}{$\begin{array}{l}\text { Actual FER } \\
\text { costs for evapo- } \\
\text { ration of } 1 \mathrm{~kg} \text { of } \\
\text { water, MJ }\end{array}$} & \multirow{2}{*}{$\begin{array}{c}\text { Specific } \\
\text { cost } \\
\text { UAH / MJ }\end{array}$} \\
\hline & & $\mathrm{kWh}$ & MJ & & & & & \\
\hline Electricity & 1 & 177 & 636 & 7,7 & $517^{*}$ & 9,2 & - & 0,812 \\
\hline Diesel fuel & 111,7 & 2106 & 7582 & 92,3 & $5085^{*}$ & $\begin{array}{l}90,8 \\
\end{array}$ & 3,79 & 0,671 \\
\hline Total & & 2751 & 8218 & 100 & 5602 & $\begin{array}{ll}100 \\
\end{array}$ & & \\
\hline
\end{tabular}

* The tariff for electricity for enterprises is 292 kopecks / kWh, for 1 liter of liquid fuel - 28.25 UAH

1.5 [13]. In this case, the specific consumption of electricity for its production is about $177 \mathrm{kWh} / \mathrm{t}$ or $636 \mathrm{MJ} / \mathrm{t}$ (with an initial moisture content of forage grasses of $70 \%)$. Moreover, the analysis of the structure of electrici ty costs shows that most of it, $66 \%$, falls on the drying process [14]. But when drying, not only electricity is used as a source of energy, but also fuel. The fuel and energy balance of this technology (Table 1) shows that diesel fuel provides about $92.3 \%$ of all equipment needs for energy, and its cost is $90.8 \%$ of the total cost of all fuel and energy resources (FER). On the other hand, electricity accounts for only $7.7 \%$ of the total needs, and the costs of paying for it also serve $9.2 \%$ of the total costs of purchasing fuel and energy resources.

That is, the conducted fuel and energy balance of the technology for the production of granular herbal flour implies that the most expensive source of energy used in the drying process is fuel. The high market cost of fuel, combined with its growing share in the formation of the cost of finished products, leads to the economic inexpediency of restoring plants for the production of grass meal. Therefore, at one time, a scientific hypothesis was put forward that the technology of processing grass cutting in compound feed production will be energy efficient in terms of replacing the energy obtained from fuel with electric energy or avoiding the drying process altogether.

At the Odessa National Academy of Food Technologies, at the Department of Feed and Biofuel Technology, a new technological method for the production of feed products using wet feed products without their preliminary or subsequent drying has been proposed and scientifically substantiated, which reveals the resource reserves of the raw material base of feed production, including through forage grasses and green mass of cultivated plants, etc. [15]. In the new technology, the leading place belongs to the extrusion process, the task of which, in addition to increasing the feed value and disinfection, is also the dehydration.

The purpose of the work is to study the energy feasibility of using extrusion for dehydration of wet feed products during their complex processing in feed products. solved:

To achieve this goal, the following tasks were

-the selection and calculation of the necessary technological equipment for the principle technological scheme of the production of feed products with the inclusion of wet forage grasses was carried out;

-an energy audit of the basic (traditional) and new technologies for the production of compound feed products with the inclusion of forage grasses was carried out.

Research materials and methods
The determination of the energy efficiency potential is carried out through a comparative energy audit of innovative and basic technologies. It is based on calculating the amount of consumed energy, energy balance and comparing the values obtained in the study of the existing traditional technology for the production of grass flour, basic and new technologies for the production of feed products.

For this, proceeding from the principle flow diagram of the production of feed products, from the beginning we carry out the selection and calculation of the necessary technological equipment according to the methods given in [16].

At feed mills, energy consumption is recorded by fixing the amount of received energy carriers. Therefore, when carrying out an energy audit of the basic and unchanged section of the improved technology, we use the passport data of the equipment, and in the case of a new technology in the areas subject to changes - the data of experimental studies [17, 18].

Experimental production of samples and a pilot batch of loose and extruded feed concentrate of the developed composition [14] with the inclusion of cutting blue hybrid alfalfa in an amount of $20 \%$, dried to a moisture content of $70 \%$, was carried out in accordance with the recommendations of the "Rules for organizing and maintaining the technological process of production of mixed feed industry "[19].

The technological process of extrusion of experimental feed samples was carried out in ONAFT at the Department of Feed and Biofuel Technology in an EZ150 extruder (Bronto). The productivity of the extruder was determined by weighing the mass released from the outlet of the screw part of the extruder for 20 minutes. The result obtained, multiplied by 3 , characterizes the hourly productivity of the installation. To bring the productivity to the nominal density of $750 \mathrm{~kg} / \mathrm{m}^{3}$, the obtained value of the productivity is multiplied by the coefficient determined by dividing the conditional density by the actual one. The capacity of the installation is determined under the condition that the current load of the main electric motor is $100 \%$, the quality of the extruded product is satisfactory, and the temperature is correct. Before starting work, an ammeter and a wattmeter are connected to the extruder to determine the power characteristics. After starting, the press is brought to a mode in which its performance, process temperature and current load of the electric motor must correspond to the nominal value.

The power of the electric motor of the extruder was determined at intervals of 2 - 5 minutes by measuring the mains voltage, current consumption and power 
factor. The measurement of these quantities is carried out using a voltmeter, ammeter and phase meter, respectively [20]. Power is calculated by the formula:

$$
N=U \cdot I \cdot \cos \varphi
$$

де $U$ - mains voltage, $\mathrm{V}$;

$I$ - consumed network current, A;

$\cos \varphi-$ power factor.

The total installed power is calculated as the product of the power of the technological equipment electric motor by its quantity. A similar calculation is carried out for each of the technological lines and its results are used to calculate the specific consumption of electricity in energy and estimated terms for each of the technological lines. Specific electricity consumption in energy terms is determined by the formula:

$$
N_{\text {num }}=\frac{\sum N}{Q}
$$

where $\Sigma N$ - total power consumption of electric motors of the equipment performing this operation, stage, etc., $\mathrm{kW}$;

$Q$ - productivity of the equipment (lines), $\mathrm{kg} / \mathrm{h}$.

Specific electricity consumption in estimated terms is calculated by multiplying the specific electricity consumption in energy terms by the current industrial electricity tariff. Next, the total electricity costs are calculated for the entire technology (basic and new) at actual humidity. For correct comparison and analysis of the obtained values, we list them on dry matter.

\section{Research results}

Since the new technology is recommended to be implemented at feed mills of small capacity due to the proximity of raw materials, it must be able to process forage grasses in an amount no less than the basic technology for the production of grass meal. The minimum capacity of the ABM-type drying unit for cooking is 0.65 $\mathrm{t} / \mathrm{h}$ for grass meal $(2.7 \mathrm{t} / \mathrm{h}$ for raw materials). For the design of the technological process, the selection and calculation of the necessary technological equipment for the basic and new technologies for the production of feed products, we take the capacity of $18 \mathrm{t} / \mathrm{h}$. For the implementation of these technologies, according to the developed recipe, the lines given in table 2 are provided. [2123].

To calculate the technological equipment for each of the technological lines, we take the following raw material costs: grain $60 \%$, oil meals $15 \%$, meals $-20 \%$, forage grasses $15 \%$, mineral raw materials $4 \%$, premix $1 \%$, granulated grass flour $-5 \%$. The final results of the selection and calculation of the required technological equipment are shown in Table 2.

Based on the data obtained, we determine the specific consumption of electricity in energy and estimated terms (Table 3 ).

Thus, the savings in electricity during the implementation of the new technology with the selected variant of the technological scheme in comparison with the base one are $84.6 \mathrm{~kW} \cdot \mathrm{h} / \mathrm{t}$ or $\sim 247.03 \mathrm{UAH} / \mathrm{t}$ of dry matter. However, in the basic technology, the production of grass meal is carried out by high-temperature drying, which uses diesel fuel. Therefore, in order to correctly compare the specific energy consumption of the basic and new technologies, a comprehensive technical and economic analysis of all fuel and energy resources was carried out (Table 4).

The technical and economic analysis of the fuel and energy resources costs showed that the elimination of the energy-intensive drying process even when using non-energy-intensive extrusion can significantly reduce the cost of fuel and energy resources. Fuel economy is 9 $1 / \mathrm{t}(379 \mathrm{MJ} / \mathrm{t})$, and electricity savings - $32 \mathrm{MJ} / \mathrm{t}$ (in terms of dry matter of compound feed) or in estimated terms 252.25 UAH/t and 25.85 UAH/t, respectively.

\begin{tabular}{|c|c|c|c|c|c|}
\hline \multirow{3}{*}{ Technological line name } & \multirow{3}{*}{$\begin{array}{l}\text { Line capacity, } \\
\text { t/hour }\end{array}$} & \multicolumn{4}{|c|}{ Total installed capacity by technology } \\
\hline & & \multicolumn{2}{|c|}{ basic } & \multicolumn{2}{|c|}{ new } \\
\hline & & $\mathrm{kW}$ & MJ & $\mathrm{kW}$ & MJ \\
\hline Grain preparing line & 10.0 & 151.4 & 545 & 151.4 & 545 \\
\hline Grain extrusion line & 10.0 & 1603 & 5760.5 & - & - \\
\hline Oil meal preparing line & 2.7 & 57.2 & 205.9 & 57.2 & 205.9 \\
\hline Preparing line of meal ingredients & 3.6 & 2.2 & 7.9 & 2.2 & 7.9 \\
\hline Preparing line of mineral ingredients & 0.72 & 23.5 & 84.6 & 23.5 & 84.6 \\
\hline Line of pelleted grass meal & 0.9 & 24.2 & 87.1 & 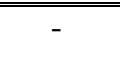 & 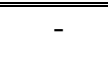 \\
\hline Line of cut grass & 2.7 & - & - & 26.1 & 94 \\
\hline Line mixtures of free-flowing components & 15.3 & - & - & 23.5 & 84.6 \\
\hline Main dosing and mixing line & 18.0 & 23.5 & 84.6 & 10 & 36 \\
\hline Compound feed pelletizing line & 18.0 & 437.3 & 1574.3 & 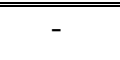 & - \\
\hline Compound feed extrusion line & 18.0 & - & - & 2193.7 & 78797.3 \\
\hline
\end{tabular}

Table 2 - Calculation of technological equipment 
Table 3 - Comparative energy audit

\begin{tabular}{|c|c|c|c|c|c|c|}
\hline \multirow{4}{*}{ Name of technological line } & \multicolumn{6}{|c|}{ Specific electricity consumption for technology in terms of } \\
\hline & \multicolumn{4}{|c|}{ energetic } & \multicolumn{2}{|c|}{ estimated, $\mathrm{UAH} / \mathrm{t}$} \\
\hline & \multicolumn{2}{|c|}{ basic } & \multicolumn{2}{|c|}{ new } & \multirow{2}{*}{ basic } & \multirow{2}{*}{ new } \\
\hline & $\mathrm{kW} \cdot \mathrm{h} / \mathrm{t}$ & $\mathrm{MJ} / \mathrm{t}$ & $\mathrm{kW} \cdot \mathrm{h} / \mathrm{t}$ & $\mathrm{MJ} / \mathrm{t}$ & & \\
\hline Grain preparing line & 15.1 & 54.5 & 15.1 & 54.5 & 44.09 & 44.09 \\
\hline Grain extrusion line & 160.2 & 576.0 & 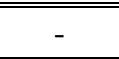 & 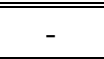 & 467.78 & 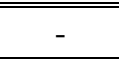 \\
\hline Oil meal preparing line & 21.2 & 76.3 & 21.2 & 76.3 & 61.90 & 61.90 \\
\hline Preparing line of meal ingredients & 0.6 & 2.2 & 0.6 & 2.2 & 1.75 & 1.75 \\
\hline Preparing line of mineral ingredients & 32.6 & 117.5 & 32.6 & 117.5 & 95.19 & 99.19 \\
\hline Line of pelleted grass meal & 26.9 & 96.8 & 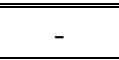 & 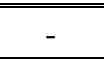 & 78.55 & 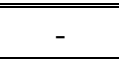 \\
\hline Line of cut grass & - & - & 9.7 & 34.8 & - & 28.32 \\
\hline Line mixtures of free-flowing components & - & - & 1.5 & 5.5 & - & 4.38 \\
\hline Main dosing and mixing line & 1.3 & 4.7 & 0.6 & 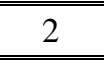 & 3.80 & 1.75 \\
\hline Compound feed pelletizing line & 29.3 & 87.5 & - & - & 85.56 & - \\
\hline Compound feed extrusion line & - & - & 121.9 & 438.7 & - & 355.95 \\
\hline $\begin{array}{l}\text { Total for technology: } \\
\text { At actual moisture content } \\
\text { Based on dry matter }\end{array}$ & $\begin{array}{l}282.4 \\
320.9\end{array}$ & $\begin{array}{l}1015.4 \\
1153.9\end{array}$ & $\begin{array}{l}203.2 \\
236.3\end{array}$ & $\begin{array}{l}731.5 \\
850.6\end{array}$ & $\begin{array}{l}838.62 \\
952.98\end{array}$ & $\begin{array}{l}593.33 \\
689.92\end{array}$ \\
\hline
\end{tabular}

Table 4 - Feasibility study of fuel and energy resources, per 1 ton of dry matter

\begin{tabular}{|c|c|c|c|c|c|}
\hline \multirow{3}{*}{ Production technology } & \multicolumn{5}{|c|}{ Costs for fuel and energy resources in expression } \\
\hline & \multicolumn{2}{|c|}{ energy, MJ } & \multicolumn{3}{|c|}{ estimated, UAH } \\
\hline & electricity & diesel fuel & electricity & diesel fuel & total \\
\hline Grass flour & 636 & 7582 & 517 & 5085 & 5602 \\
\hline Compound feed concentrates & 1154 & - & 953 & - & 953 \\
\hline Total (compound feed with 5\% grass flour) & 1186 & 379 & 978,85 & 252.25 & 1231.1 \\
\hline Extruded feed concentrates (new) & 689.92 & - & 689,92 & - & 689.92 \\
\hline
\end{tabular}

\section{Conclusions}

Thus, an energy audit of the basic (traditional) and new technology for the production of mixed feed products with the inclusion of forage grasses was carried out and proved that as a result of the use of the extrusion process for the purpose of dehydration, the new technol-

\section{REFERENCES}

ogy becomes more energy efficient in comparison with the traditional technology of drying forage grasses and further production of products with the inclusion of grass flour, which means it is economically feasible, since there is a total saving of fuel and energy resources of 875 $\mathrm{MJ} / \mathrm{t}$ or - in the amount of $514.18 \mathrm{UAH}(44 \%)$.

1. Bevz, V.V. Enerhoefektyvnist' pidpryyemstv kharchovoyi promyslovosti - suchasnyy stan i stratehiya rozvytku [Tekst] / V. V. Bevz // Naukovi pratsi Natsional'noho universytetu kharchovykh tekhnolohiy. - 2010. - T. 1. - №. 35 - S. 15 - 17.

2. Bevz, V. V. Enerhozberezhennya - potentsial rozvytku ekonomiky Ukrayiny [Tekst] / V. V. Bevz,// Kharchova promyslovist'. - 2010. - № 9. - S. 186-190.

3. Bevz, V. V. Enerhozberezhennya - efektyvnyy shlyakh do znyzhennya vytrat vyrobnytstva [Tekst] / V. V. Bevz.// Kharchova promyslovist'. - 2010. - № 9. - S. 190-194.

4. Bevz, V. V. Znyzhennya enerhoyemnosti produktsiyi - innovatsiynyy shlyakh rozvytku pidpryyemstv kharchovoyi promyslovosti [Tekst] / V. V. Bevz // Finansy, oblik, audyt: zb. nauk. prats'. - K.: KNEU. - 2011. - № 17. - S. 16-24.

5. Matsevytbly, Yu.M. Perspektyvbl эnerho- y resursosberezhenyya na osnove yntehratsyonnoy modely razvytyya terrytoryal'no-prombishlennukh kompleksov [Tekst] / Yu.M. Matsevytbly, V.V. Solovey, A.Y. Vasyl'ev // Tekhnolohycheskyy audyt y rezervbl proyzvodstva. - 2014. - № 6/1 (20). - S. $26-31$.

6. Kaynov, A. Kompleksnaya lynyya po proyzvodstvu travyanoy muky [Tekst]/ A. Kaynov// Kombykorma. - 2012. - № 4. S.41-42.

7. Zafren, S. Ya. Tekhnolohyya pryhotovlenyya kormov [Tekst]/ S.Ya. Zafren //M.: Kolos. - 1977. - 239 s.

8. Sokhansanj, S. Kinetics of dehydration of green alfalfa [Text] /S. Sokhansanj, R. T. Patil //Drying technology. - 1996. - T. 14. - №. 5. - S. 1197-1234.

9. Wood, H.C. Heat treatment of chopped alfalfa in rotary drum dryers [Text]/ H.C. Wood, S. Sokhansanj // Journal: Drying Technology. - Volume 8, Issue 3, January 1990. - R. 543-569.

10. Patil, R. T. Thin layer drying of components of fresh alfalfa [Text] / R. T. Patil and all// Canadian Agricultural Engineering. - 1992. - T. 34. - S. 343-343. 
11. Wu, H. Alfalfa drying properties and technologies-in review [Text] / H. Wu //Nature and Science. - 2004. - T. 2. - № 4. - S. 65-67.

12. Guillemot, E. The European alfalfa drying system Rezhym dostupu http://alfalfa.ucdavis.edu/ symposium/2011/files/talks/11WAS-3_Guillemont_EuropeanSystems.pdf

13. Kuchynskas, Z.M. Oborudovanyya dlya sushky, hranulyrovanyya y bryketyrovanyya kormov [Tekst] / Z.M. Kuchynskas, V.Y. Osobov, Yu.L. Fruher. - M.: Ahropromyzdat, 1988. - 208 s.

14. Ehorov, B. V. Эkstrudyrovanye pry pererabotke kombykormov povblshennoy vlazhnosty [Tekst] / B. V. Ehorov, O. H. Burdo, V. V. Honcharenko, N. V. Khorenzhyy // Khranenye y pererabotka zerna. - 2005. - № 9. - S.33 - 37 .

15. Khorenzhyy, N.V. Otsinka produktyvnoyi diyi kombikormovoyi produktsiyi iz vklyuchennyam volohykh kormovykh trav u hodivli velykoyi rohatoyi khudoby [Tekst] // Nauk. pratsi / ONAKhT. - O., 2014. - Vyp. 46. T. 1. - S. 70 - 76.

16. Yehorov, B. V. Metodychni vkazivky do vykonannya kursovoho ta dyplomnoho proektuvannya dlya studentiv profesiynykh napryamiv pidhotovky 7.05170101, 8.05170101 dennoyi ta zaochnoyi form navchannya. U 3-kh ch. [Tekst] / Yehorov B.V., Kochetova A.O., Makarov O.P., Brazhenko V.Ye., Pulatov V.B. - Odesa, ONAKhT, 2011.

17. Budro, O.H. Metodycheskye ukazanyya k yzuchenyyu kursa «Osnovbl эnerhetychekoho menedzhmenta» [Tekst] / O.H.Burdo. Odessa, ONAPT, 2003 h. -40 s.

18. Burdo, O.H. Эnerhetycheskyy monytorynh pyshchevblkh proyzvodstv [Tekst]/ O.H.Burdo - Odessa: Polyhraf, 2008. - 244s.

19. Pravylakh orhanizatsiyi $i$ vedennya tekhnolohichnoho protsesu vyrobnytstva kombikormovoyi produktsiyi [Tekst]. - K.: Ministerstvo ahropromyslovoho kompleksu Ukrayiny, Kyyivs'kyy instytut khliboproduktiv, 1998. - 220 s.

20. Prakhovnyk, A.V. Эnerhetycheskyy menedzhment [Tekst] / A.V. Prakhovnyk, A.Y. Solovey, V.V. Prokopenko y dr. - K.: IEENTUU «KPY», 2001. - 472 s.

21. Ehorov, B.V. Эkstrudyrovannble kombykorma na osnove lyutsernovoy rezky [Tekst] / B.V. Ehorov, V.V. Honcharenko, N.V. Khorenzhyy // Zernovi produkty i kombikormy. - 2004. - № 3. - S. $30-34$

22. Yehorov, B.V. Tekhnolohichni osnovy portsiynoyi tekhnolohiyi vyrobnytstva kombikormiv dlya velykoyi rohatoyi khudoby [Tekst]/ B.V. Yehorov, N.V. Khorenzhyy// Zb.dop. mizhnar. konf. "Ukrayina. Kombikormy-2004"-Kyyiv, 2004. - S. 70-72.

23. Ehorov, B.V. Эkstrudyrovannble kombykorma na osnove lyutsernovoy rezky [Tekst]/ B.V. Ehorov, V.V. Honcharenko, N.V. Khorenzhyy // Khranenye y pererabotka zerna. - 2004. - № 9. - S. 37 - 39.

Б.В. Сгоров ${ }^{1}$, д-р техн. наук, академік УНААН, професор, E-mail: bogdanegoroff58@ gmail.com, https://orcid.org/0000-0001-7526-0315, ResearcherID: Q-1365-2015, Scopus Author ID: 56578802600

Н.В. Хоренжий ${ }^{2}$, канд. техн. наук, доцент, E-mail: natalka.onaft@gmail.com, http://orcid.org/0000-0001-7912-4791, ResearcherID: B-3897-2016

${ }^{1}$ Кафедра технологї комбікормів і біопалива ${ }^{2}$ Кафедра технології переробки зерна Одеська національна академія харових технологій, 112, Канатна, Одеса, Україна, 65039

\section{ВИЗНАЧЕННІ ВНУТРІШНЬОГО ПОТЕНЦАЛУ ЕНЕРГОЕФЕКТИВНОСТІ У КОМБІКОРМОВОМУ ВИРОБНИЦТВІ}

\section{Анотація.}

Трав'яне борошно - унікальний білково-вітамінний кормовий засіб, роль якого в годівлі тварин важко переоцінити. У 2010 році індустрія виробництва трав'яного борошна з люцерни, наприклад, в Свропі включала 300 заводів та 50 фермерських господарств, які виготовляли 4200 млн.т продукиії. В Росї також розвиток птахівницчтва та тваринництва підвищчв попит на ичей кормовий засіб та поступово відновив його виробництво. Але в Україні внаслідок своєї високої енергоємності виробництво трав'яного борочна майже припинилось. Паливоенергетичний баланс иієї технології показує, щзо дизельне паливо забезпечує біля 92,3 \% всіх потреб обладнання в енергіі, а його вартість складає 90,8\% від загальних витрат на всі паливно-енергетичні ресурси. На електрику ж припадає лише 7,7 \% від загальних потреб, а витрати на їі оплату становлять також 9,2 \% від загальних витрат на придбання паливно-енергетичних ресурсів. В Одеській наџіональній академії харчових технологій на кафедрі технології комбікормів і біопалива запропоновано та науково обтрунтовано новий технологічний спосіб виробництва комбікормової продукиії з використанням вологих кормових засобів без їх попереднього або наступного сушіння, який розкриває резерви ресурсів сировинної бази комбікормового виробництва, у тому числі за рахунок кормових трав та зеленої маси культурних рослин, тощз. Мета роботи полягає у вивченні енергетичної дочільності застосування екструдування для зневоднення вологих кормових засобів при комплексній їх переробиі в комбікормову продукцію. Для досягнення поставленої мети вирішені наступні задачі: проведено підбор та розрахунок необхідного технологічного обладнання для принципової технологічної схеми виробництва комбікормової продукції 3 включенням вологих кормових трав; проведено енергетичний аудит базової (традиційної) та нової технологї виробництва комбікормової продукиії з включенням кормових трав. Оскільки нову технологію рекомендовано реалізовувати на комбікормових підприємствах невеликої потужності через близькість сировини, вона повинна бути спроможною переробляти кормові трави в обсязі, не меншому ніж базова технологія виробництва трав'яної муки. Мінімальна продуктивність сушарного агрегату типу АВМ для приготування складає 0,65 m/год по трав'яній муці (2,7 m/год по сировині). Таким чином проведений енергетичний аудит базової (традиційної) та нової технології виробництва комбікормової продукції з включенням кормових трав доказав, щуо в результаті застосування процесу екструдування з метою зневоднення нова технологія стає більш енергоефективною у порівнянні з традиційною технологією сушіння кормових трав та подальшого виробництва продукиії з включенням трав'яної муки, а 
значить і економічно дочільною, оскільки відбувається загальна економія ПЕР 875 МДж/m або - на суму 514,18 грн $(44 \%)$.

Ключові слова: енергоефективність, електроенергія, паливо, паливно-енергетичні ресурси, екструдування, комбікорм, трав'яна мука

1. Бевз, В.В. Енергоефективність підприємств харчової промисловості - сучасний стан і стратегія розвитку [Текст] / В. В. Бевз // Наукові праці Національного університету харчових технологій. - 2010. - Т. 1. - №. 35 - С. 15 - 17.

2. Бевз, В. В. Енергозбереження - потенціал розвитку економіки України [Текст] / В. В. Бевз // Харчова промисловість. - 2010. — № 9. - C. 186-190.

3. Бевз, В. В. Енергозбереження - ефективний шлях до зниження витрат виробництва [Текст] / В. В. Бевз // Харчова промисловість. — 2010. — № 9. - С. 190-194.

4. Бевз, В. В. Зниження енергоємності продукції - інноваційний шлях розвитку підприємств харчової промисловості [Текст] / В. В. Бевз // Фінанси, облік, аудит: зб. наук. праць. - К.: КНЕУ. - 2011. - № 17. - С. 16-24.

5. Мацевитый, Ю.М. Перспективы энерго- и ресурсосбережения на основе интеграционной модели развития территориально-промышленных комплексов [Текст] / Ю.М. Мацевитый, В.В. Соловей, А.И. Васильев // Технологический аудит и резервы производства. - 2014. - № 6/1 (20). - С. 26 - 31.

6. Кайнов, А. Комплексная линия по производству травяной муки [Текст] / А. Кайнов// Комбикорма. - 2012. - № 4. - С. 41-42.

7. Зафрен, С. Я. Технология приготовления кормов [Текст]/ С.Я. Зафрен //М.: Колос. - 1977. - 239 с.

8. Sokhansanj, S. Kinetics of dehydration of green alfalfa [Text] / S. Sokhansanj, R. T. Patil //Drying technology. - 1996. - T. 14. - №. 5. - C. 1197-1234.

9. Wood, H.C. Heat treatment of chopped alfalfa in rotary drum dryers [Text]/ H.C. Wood, S. Sokhansanj // Journal: Drying Technology. - Volume 8, Issue 3, January 1990. - P. 543-569.

10. Patil, R. T. Thin layer drying of components of fresh alfalfa [Text] / R. T. Patil and all// Canadian Agricultural Engineering. 1992. - T. 34. - C. 343-343.

11. Wu, H. Alfalfa drying properties and technologies-in review [Text] / H. Wu //Nature and Science. - 2004. - T. 2. - № 4. - C. 65-67.

12. Guillemot, E. The European alfalfa drying system. URL: http://alfalfa.ucdavis.edu/+symposium/2011/files/talks/11WAS3_Guillemont_EuropeanSystems.pdf (cited 20/01/2020)

13. Кучинскас, 3.М. Оборудования для сушки, гранулирования и брикетирования кормов [Текст] / 3.М. Кучинскас, В.И. Особов, Ю.Л. Фругер. - М.: Агропромиздат, 1988. - 208 с.

14. Егоров, Б. В.Экструдирование при переработке комбикормов повышенной влажности [Текст] / Б. В. Егоров, О. Г. Бурдо, В. В. Гончаренко, Н. В. Хоренжий // Хранение и переработка зерна. - 2005. - № 9. - С.33 - 37.

15. Хоренжий, Н.В. Оцінка продуктивної дії комбікормової продукції із включенням вологих кормових трав у годівлі великої рогатої худоби [Текст] // Наук. праці / ОНАХТ. - О., 2014. - Вип. 46. Т. 1. - С. 70 - 76.

16. Сгоров, Б. В. Методичні вказівки до виконання курсового та дипломного проектування для студентів професійних напрямів підготовки 7.05170101, 8.05170101 денної та заочної форм навчання. У 3-х ч. [Текст] / Сгоров Б.В., Кочетова А.О., Макаров О.П., Браженко В.С., Пулатов В.Б. - Одеса, ОНАХТ, 2011.

17. Будро, О.Г. Методические указания к изучению курса «Основы энергетичекого менеджмента» [Текст] / О.Г.Бурдо. Одесса, ОНАПТ, 2003 г. - 40 с.

18. Бурдо, О.Г. Энергетический мониторинг пищевых производств [Текст] / О.Г.Бурдо - Одесса: Полиграф, 2008. - 244 с.

19. Правилах організації і ведення технологічного процесу виробництва комбікормової продукції [Текст]. - К.: Міністерство агропромислового комплексу України, Київський інститут хлібопродуктів, 1998. - 220 с.

20. Праховник, А.В. Энергетический менеджмент [Текст] / А.В. Праховник, А.И. Соловей, В.В. Прокопенко и др. - К.: IЕЕНТУУ «КПИ», 2001. - $472 \mathrm{c}$.

21. Егоров, Б.В. Экструдированные комбикорма на основе люцерновой резки [Текст] / Б.В. Егоров, В.В. Гончаренко, Н.В. Хоренжий // Зернові продукти і комбікорми. - 2004. - № 3. - С. 30 - 34

22. Єгоров, Б.В. Технологічні основи порційної технології виробництва комбікормів для великої рогатої худоби [Текст] / Б.В. Єгоров, Н.В. Хоренжий // Зб. доп. міжнар. конф.“Україна. Комбікорми-2004”-Київ, 2004. - С. 70-72.

23. Егоров, Б.В. Экструдированные комбикорма на основе люцерновой резки [Текст]/ Б.В. Егоров, В.В. Гончаренко, Н.В. Хоренжий // Хранение и переработка зерна. - 2004. - № 9. - С. 37 - 39.

\section{Received 25.10.2020 \\ Reviewed 07.12.2020}

Revised 30.01.2021

Approved 30.03.2021

\section{Cite as Vancouver Citation Style}

Iegorov B., Khorenzhy N. Determination of the internal potential of energy efficiency in compound feed production // Grain Products and Mixed Fodder's, 2021. 21. 1 (81).: 37-42. DOI https://doi.org/

Cite as State Standard of Ukraine 8302:2015

Determination of the internal potential of energy efficiency in compound feed production / Iegorov B. et al. // Grain Products and Mixed Fodder's, 2021. Vol. 21. I. 1 (81). P. 37-42. DOI https://doi.org/ 